\title{
Hibernation of predatory arthropods in semi-natural habitats
}

\author{
Flavia Geiger · Felix L. Wäckers · \\ Felix J. J. A. Bianchi
}

Received: 4 March 2008/ Accepted: 8 December 2008/Published online: 28 December 2008

(C) The Author(s) 2008. This article is published with open access at Springerlink.com

\begin{abstract}
Non-crop habitats provide important resources for natural enemies. Many natural enemies hibernate in non-crop habitats, from which they may colonise arable fields in the spring. Spring colonisation ensures annual repopulation of the crop with natural enemies, allowing them to keep pace with the development of pest populations. The availability of non-crop habitats can, therefore, be crucial to successful conservation biological control. We quantified the density of overwintering natural enemies near organic Brussels sprout crops in five different non-crop habitats (short grassy field margin, herbaceous field margin, herbaceous field margin under a tree line, ditch and forest). Soil and litter samples of non-crop habitats were taken at two sites. One site was located in an open agricultural landscape, the other in a landscape dominated by mixed forest.
\end{abstract}

Handling Editor: Arne Janssen.

F. Geiger $(\bowtie)$

Nature Conservation and Plant Ecology, Wageningen University and Research Centre, P.O. Box 47, 6700 AA Wageningen, The Netherlands

e-mail: flavia.geiger@wur.nl

F. L. Wäckers

Centre for Sustainable Agriculture, Lancaster University,

L.E.C., Lancaster, UK

F. J. J. A. Bianchi

CSIRO Entomology, 120 Meiers Road, Indooroopilly, QLD 4068, Australia
Insects belonging to Staphylinidae, Araneae, Carabidae, Coccinellidae and Dermaptera were the most abundant. Mean densities of predatory arthropods were higher in the open agricultural landscape (290 predators $\mathrm{m}^{-2}$ ) than in the forested landscape (137 predators $\mathrm{m}^{-2}$ ). Herbaceous habitat types supported the highest densities of overwintering predators (up to 400 predators $\mathrm{m}^{-2}$ ), whereas densities in the forest were lowest $\left(10\right.$ predators $\left.\mathrm{m}^{-2}\right)$. These results indicate that herbaceous non-crop habitats are important refugia for predators and may play a vital role in conservation biological control.

Keywords Agroecosystems · Predators · Conservation biological control - Overwintering . Non-crop habitat $\cdot$ Pest control

\section{Introduction}

Habitat diversity may facilitate natural pest control in annual arable cropping systems (Gurr et al. 2003; Tscharntke et al. 2007). However, agricultural intensification tends to lead to the simplification of landscape composition and the reduction of habitat diversity (Westmacott and Worthington 1997; Manhoudt and de Snoo 2003). Non-crop habitats like forests, hedgerows, tree lines, field margins and ditchbanks are essential for the conservation of a diversity of natural enemies in agricultural landscapes 
that can play a role in suppressing pest populations in crops (Duelli and Obrist 2003; Bianchi et al. 2006). Non-crop habitats may provide plant-derived food resources, e.g. nectar or pollen, alternative prey, refuge from pesticides and other disturbances, shelter, a moderate microclimate and hibernation sites (Landis et al. 2000). By providing these resources, non-crop habitats can support natural enemy populations and help enhance their impact on pest population dynamics (Wilkinson and Landis 2005).

The majority of natural enemies depends on noncrop habitats for overwintering, as bare fields are generally less suitable for hibernation (Andersen 1997; Pfiffner and Luka 2000). The presence of hibernation sites near crop fields allows an effective early season colonisation of crops, which may result in effective pest suppression (Coombes and Sotherton 1986; Dennis and Fry 1992; Bianchi and van der Werf 2003). Especially, polyphagous predators, such as Carabidae, Staphylinidae and Araneae, may play an important role in pest regulation in the spring because of their early activity and broad food range (Chiverton 1986; Chang and Kareiva 1999; Symondson et al. 2002). Besides the spatial distribution of crop and non-crop habitats in the agroecosystem, the vegetation structure of non-crop habitats may also play an essential role in the winter survival of arthropods (Dennis et al. 1994; Pfiffner and Luka 2000).

In this study, we compared different types of noncrop habitats adjacent to Brussels sprouts fields with respect to densities and the community structure of overwintering predator populations. The identification of suitable hibernation sites contributes to our understanding of predator-prey interactions in agroecosystems and may provide tools to enhance conservation biological control.

\section{Materials and methods}

The study was conducted at two sites, Achterberg and Wageningen-Hoog, which are located near Wageningen, the Netherlands. The site in Wageningen-Hoog is surrounded by mixed forest, whereas the site in Achterberg is surrounded by grassland and arable crops. Brussels sprouts fields of approximately $800 \mathrm{~m}^{2}$ were established at both sites. Brussels sprout was grown under organic management in order to exclude possible undesirable effects of synthetic agrochemicals on natural enemy densities. The fields were surrounded by different types of non-crop habitats. Mowed grassy field margins and unmowed herbaceous field margins (various herbaceous and grassy species) occurred in both Achterberg and Wageningen-Hoog. A herbaceous field margin under a tree line (beech) and mixed forest was only present in Wageningen-Hoog, while a ditchbank with tall grass (approximately $50 \mathrm{~cm}$ ) was only found in Achterberg. Sampling took place in the first week of December 2003. In each non-crop habitat, ten samples were taken in a transect at 1-m intervals. Samples consisted of vegetation and the upper $10 \mathrm{~cm}$ of soil in quadrates of $25 \times 25 \mathrm{~cm}^{2}$. In addition, other possible hibernation sites in the forest (e.g. under stones and under the bark of trees) were searched visually for the presence of arthropods. The samples were taken to the laboratory in plastic bags and stored at $4{ }^{\circ} \mathrm{C}$ until further processing. Samples were thoroughly broken up in white trays, after which arthropods were extracted by hand. Carabidae, Coccinellidae and Dermaptera were identified upon the species level. Staphylinidae and Araneae were identified to the genus level, except for the (sub)families Linyphiidae and Aleocharinae, which were not further identified.

\section{Statistical analyses}

Distributions of arthropod communities in the different habitat types and locations were analysed using redundancy analyses (RDA) with CANOCO 4.53 (ter Braak and Śmilauer 2002). For the analyses of group distributions at both sites and all habitat types, we used a scaling based on inter-sample distances. For RDA for the individual sites, inter-species correlations was used as the scaling method to reveal differences among species. Species scores were divided by their standard deviations. The species data table is centred by species (i.e. species are weighted by their variance).

\section{Results}

Staphylinidae, Araneae, Carabidae, Coccinellidae and Dermaptera were the most abundant taxonomic groups of natural enemies. Most specimens of Staphylinidae belonged to the sub-family Aleocharinae and the genus 
Tachyporus (Table 1). Linyphiidae and Bembidion were the most common representatives of Araneae and Carabidae, respectively. The three genera Harpalus, Dyschirius and Amara of the Carabidae family and the only species from the Coccinellidae family, i.e. Tytthaspis sedecimpunctata (Linnaeus), were excluded from the data because they are not carnivorous (Freier and Gruel 1993; Turin et al. 2000). Dermaptera were only represented by Forficula auricularia (Linnaeus).

Redundancy analyses indicate that habitat type and location account for $59 \%$ of the variance of the four major taxonomic groups (Aranaea, Staphylinidae, Carabidae and Dermaptera; Fig. 1). Predator groups were not evenly distributed over habitat and landscape type (Table 2; Fig. 1). Dermaptera were only found in the forest-dominated site (WageningenHoog). Carabidae were more numerous in Wageningen-Hoog, but also occurred in Achterberg, whereas Araneae and Staphylinidae were the dominant groups in the open landscape in Achterberg. The average predator density was higher in Achterberg $\left(288 \mathrm{~m}^{-2}\right)$ than in Wageningen-Hoog $\left(130 \mathrm{~m}^{-2}\right)$. This trend was also apparent in grassy and herbaceous field margins that occurred in both Achterberg and WageningenHoog (Fig. 2). In both sites, the highest densities of predators were found in herbaceous field margins, followed by herbaceous field margin under a tree line in Wageningen-Hoog and ditch in Achterberg, respectively (Fig. 2). In grassy field margins (Achterberg) and forest (Wageningen-Hoog), the lowest densities of hibernating predators were found. No predators were found under tree bark and stones in the forest of Wageningen-Hoog.

In Wageningen-Hoog, Araneae and Carabidae tended to be more abundant in the herbaceous field margin, whereas Staphylinidae had the highest densities in herbaceous field margins under a tree line (Table 2). RDA revealed that the species within the families of Carabidae, Staphylinidae and Araneae were not evenly distributed over the habitat types. For instance, two carabid species Bembidion quadrimaculatum (Linnaeus) and B. properans (Stephens) were strongly associated with grassy habitats, whereas the other carabid species were most abundant in the herbaceous habitats (Fig. 3). In Wageningen-Hoog, the herbaceous field margin showed the strongest correlation with the first (horizontal) RDA axis, while herbaceous field margin under a tree line showed the strongest correlation with the second (vertical) axis. The three habitats together accounted for $63 \%$ of the variance in the group composition of Carabidae. As for Araneae, the family Linyphiidae was strongly associated with grassy field margins, whereas most of the other groups were found in herbaceous field margins (data not shown).

In Achterberg, Staphylinidae and Araneae were most abundant in the herbaceous field margin, whereas Carabidae were most abundant in the ditch vegetation (Table 2). The species composition within the three taxonomic groups also differed between the habitat types in Achterberg. For example, almost all genera of Araneae were most abundant in the herbaceous field margins, except for Linyphiidae and the genus Clubiona, which preferred the grassy field margin (Fig. 4). The three habitat types together accounted for $32 \%$ of the variance in the Araneae composition. Carabid species showed a similar distribution across habitats as in Wageningen-Hoog. B. properans and Anisodactylus binotatus (Fabricius) were the only species occurring in grassy field margins, while the other species were found in herbaceous field margins or in the ditch margin (data not shown).

\section{Discussion}

We quantified the densities of hibernating natural enemies in five non-crop habitats in two contrasting landscapes. Peak densities of predators in our study (400 predators $\mathrm{m}^{-2}$ ) were lower than in other studies, where the densities ranged between 1,100 and 1,500 predators $\mathrm{m}^{-2}$ (Thomas et al. 1991; Lys and Nentwig 1994; Pfiffner and Luka 2000). These differences may reflect a variation in the predator densities between studies, but the differences may also be caused by different sampling and extraction methods. As we used similar methods to Thomas et al. (1991), i.e. 10-cm-deep soil samples and hand-sorting of arthropods, we can conclude that the predator densities in our study were indeed lower than in the study by Thomas et al. (1991). This suggests that predator densities in hibernation sites can be lower than generally assumed.

The overall density of hibernating predators were higher in the open agricultural landscape (Achterberg) as compared to the landscape dominated by 
Table 1 Overview of Staphylinidae, Araneae, Carabidae and Dermaptera found in Wageningen-Hoog (WH) and Achterberg (A) in grassy field margins (GFM), herbaceous field margins
(HFM), herbaceous field margin under a tree line (TFM), forest (F) and ditch (D). The number of specimens are indicated in brackets

\begin{tabular}{|c|c|c|c|c|}
\hline & & & WH & A \\
\hline \multirow[t]{13}{*}{ Staphylinidae } & Aleocharinae & $(146)$ & HFM, TFM, GFM, F & HFM, GFM, D \\
\hline & Tachyporus (Gravenhorst) & $(67)$ & HFM, TFM, F & HFM, GFM, D \\
\hline & Xantholinus (Dejean) & (34) & HFM, TFM & HFM, GFM, D \\
\hline & Philonthus (Stephens) & $(32)$ & TFM, F & HFM, GFM, D \\
\hline & Gabrius $^{\mathrm{a}}$ (Stephens) & (18) & HFM, TFM & HFM, GFM, D \\
\hline & Stilicus (Berthold) & (11) & HFM & HFM, GFM, D \\
\hline & Tachinus (Gravenhorst) & (5) & & HFM, GFM, D \\
\hline & Conosoma (Kraatz) & (3) & HFM & $\mathrm{D}$ \\
\hline & Stenus (Latreille) & (3) & & $\mathrm{D}$ \\
\hline & Lathrobium (Gravenhorst) & (2) & & $\mathrm{D}$ \\
\hline & Oxytelus (Gravenhorst) & (2) & & HFM \\
\hline & Trogophloeus (Mannerheim) & (1) & & $\mathrm{D}$ \\
\hline & Othius (Stephens) & (1) & TFM & \\
\hline \multirow[t]{11}{*}{ Araneae } & Linyphiidae & $(125)$ & HFM, TFM, GFM, F & HFM, GFM, D \\
\hline & Trochosa (Koch) & (26) & HFM, TFM & HFM, D \\
\hline & Pachygnatha (Sundevall) & $(25)$ & HFM, TFM & HFM, D \\
\hline & Pardosa (Koch) & (24) & TFM, GFM & HFM, GFM, D \\
\hline & Alopecosa (Simon) & (19) & HFM & HFM, D \\
\hline & Xysticus (Koch) & $(12)$ & HFM & HFM, GFM, D \\
\hline & Heliophanus (Koch) & $(11)$ & & HFM \\
\hline & Clubiona (Latreille) & (6) & HFM & GFM \\
\hline & Pisaura (Simon) & (4) & TFM & HFM, D \\
\hline & Zelotes (Gistel) & (3) & HFM & HFM \\
\hline & Juveniles & $(31)$ & HFM, TFM & HFM, GFM, D \\
\hline \multirow[t]{18}{*}{ Carabidae } & Bembidion femoratum (Sturm) & (2) & HFM & \\
\hline & Bembidion guttula (Fabricius) & (3) & & HFM, D \\
\hline & Bembidion lampros (Herbst) & $(156)$ & HFM, TFM & HFM, D \\
\hline & Bembidion properans (Stephens) & (3) & GFM & GFM, D \\
\hline & Bembidion quadrimaculatum (Linnaeus) & (1) & GFM & \\
\hline & Bembidion tetracolum (Say) & $(30)$ & HFM, TFM & HFM \\
\hline & Syntomus foveatus (Geoffroy) & $(23)$ & HFM & HFM, D \\
\hline & Syntomus truncatellus (Linnaeus) & (3) & HFM & HFM \\
\hline & Pterostichus strenuus (Panzer) & (6) & TFM & $\mathrm{D}$ \\
\hline & Pterostichus vernalis (Panzer) & (13) & HFM, TFM & HFM, D \\
\hline & Notiophilus biguttatus (Fabricius) & (3) & TFM & \\
\hline & Notiophilus palustris (Duftschmid) & (3) & HFM & HFM \\
\hline & Agonum dorsale (Pontoppidan) & (2) & & $\mathrm{D}$ \\
\hline & Agonum mиelleri (Herbst) & (2) & & HFM \\
\hline & Calathus melanocephalus (Linnaeus) & (3) & HFM & \\
\hline & Stenolophus teutonus (Schrank) & (2) & & HFM, D \\
\hline & Anisodactylus binotatus (Fabricius) & (1) & & GFM \\
\hline & Microlestes minutulus (Goeze) & (1) & & $\mathrm{D}$ \\
\hline
\end{tabular}


Table 1 continued

\begin{tabular}{lllll}
\hline & & WH & A \\
\hline & Clivina fossor (Linnaeus) & $(1)$ & & D \\
Dermaptera & Forficula auricularia (Linnaeus) & (6) & HFM, TFM & \\
\hline
\end{tabular}

${ }^{a}$ Identification is uncertain

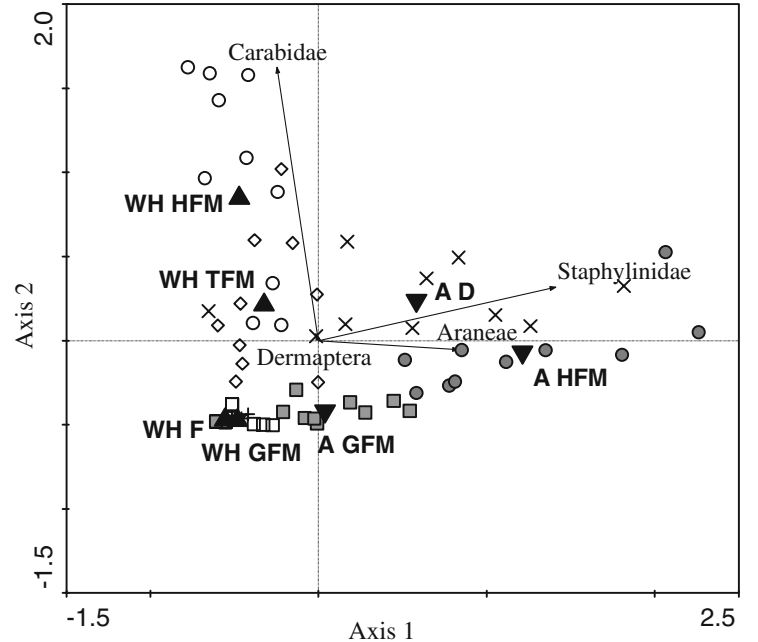

Fig. 1 Biplot diagram of the redundancy analysis focussing on the distribution of Araneae, Staphylinidae, Carabidae and Dermaptera in relation to habitat types in Wageningen-Hoog and Achterberg. The first ordination axis (axis 1) had an eigenvalue of 0.38 and species-environment correlation of 0.85 . The second ordination axis (axis 2) had an eigenvalue of 0.21 and species-environment correlation of 0.82 . WH $=$ Wageningen-Hoog (filled triangles), GFM = grassy field margin (open squares), HFM = herbaceous field margin (open circles), TFM = herbaceous field margin under a tree line (open diamonds), $\mathrm{F}=$ forest (pluses), $\mathrm{A}=$ Achterberg (upside-down filled triangles), HFM = herbaceous field margin (filled circles), GFM = grassy field margin (filled squares), $\mathrm{D}$ ditch (crosses)

Table 2 Densities of arthropods $\left(\mathrm{m}^{-2} ; n=10\right.$; SEM = standard error of the mean) and proportion (\%) of total predator densities in five habitat types in Wageningen-Hoog and

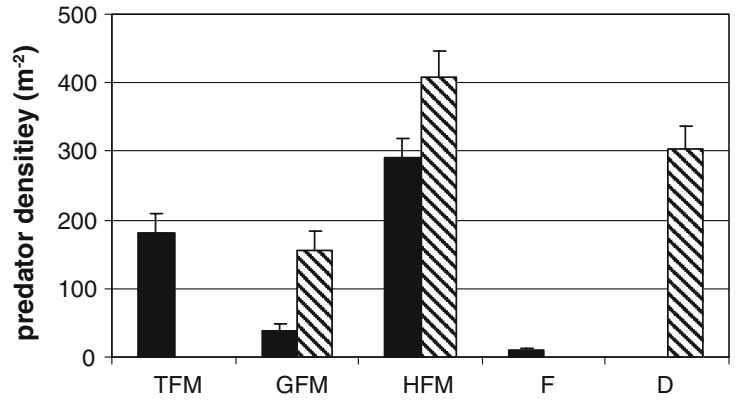

Fig. 2 Cumulative mean densities of Carabidae, Staphylinidae, Araneae and Dermaptera in grassy field margins (GFM), herbaceous field margins (HFM), herbaceous field margins under a tree line (TFM), forest (F) and ditch (D) in Wageningen-Hoog (filled bars) and/or Achterberg (hatched bars). The error bars indicate the standard error of the mean (SEM; $n=10$ )

forest (Wageningen-Hoog; Fig. 2). The higher density of predators in Achterberg may be explained by a higher pest pressure in Achterberg (Geiger, personal observation), which may have supported a larger community of predators as compared to WageningenHoog. Alternatively, the lower density of non-crop habitats in Achterberg may have resulted in a concentration of overwintering predators in the few non-crop habitats present.

Achterberg $(\mathrm{GFM}=$ grassy field margin, $\mathrm{HFM}=$ herbaceous field margin, TFM = herbaceous field margin under a tree line, $\mathrm{F}=$ forest, $\mathrm{D}=$ ditch)

\begin{tabular}{|c|c|c|c|c|c|c|c|c|c|c|c|}
\hline & \multicolumn{6}{|c|}{ Wageningen-Hoog } & \multicolumn{5}{|c|}{ Achterberg } \\
\hline & GFM & HFM & TFM & $F$ & Mean & SEM & GFM & HFM & $D$ & Mean & SEM \\
\hline Staphylinidae & 1.6 & 32 & 40 & 8 & 20.4 & 0.57 & 48 & 206.4 & 184 & 146.13 & 3.73 \\
\hline Araneae & 33.6 & 48 & 41.6 & 1.6 & 31.2 & 0.84 & 104 & 176 & 48 & 109.3 & 2.53 \\
\hline Carabidae & 3.2 & 206.4 & 94.4 & 0 & 76 & 2.48 & 3.2 & 25.6 & 70.4 & 33.1 & 1.19 \\
\hline Dermaptera & 0 & 4.8 & 4.8 & 0 & 2.4 & 0.17 & 0 & 0 & 0 & 0 & 0.00 \\
\hline Total & 38.4 & 291.2 & 180.8 & 9.6 & 130 & 3.28 & 155.2 & 408 & 302.4 & 288.5 & 4.89 \\
\hline$\%$ & 7.4 & 56 & 34.8 & 1.8 & & & 17.9 & 47.1 & 34.9 & & \\
\hline
\end{tabular}




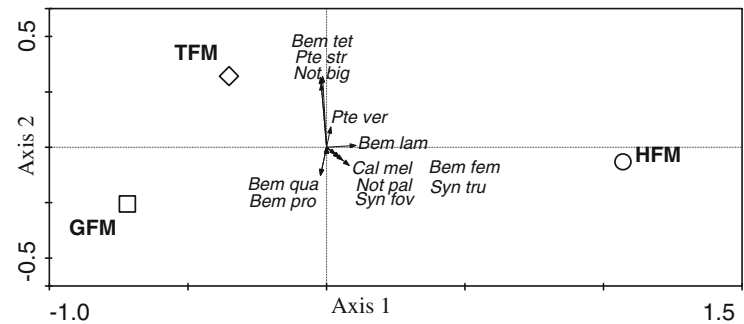

Fig. 3 Biplot diagram of the redundancy analysis focussing on the distribution of carabid species in Wageningen-Hoog in grassy (GFM), herbaceous (HFM) and herbaceous field margins under a tree line (TFM). Forest is not included because carabid species were not found in the forest soil. Species scores are divided by their standard deviations. The first ordination axis (axis 1) had an eigenvalue of 0.59 and species-environment correlation of 0.84 . The second ordination axis (axis 2) had an eigenvalue of 0.04 and speciesenvironment correlation of 0.53. Bem fem = Bembidion femoratum (Sturm), Bem lam = B. lampros (Herbst), Bem pro $=B$. properans (Stephens), Bem tet $=B$. tetracolum (Say), Bem qua =B. quadrimaculatum (Linnaeus), Cal mel = Calathus melanocephalus (Linnaeus), Not big = Notiophilus biguttatus (Duftschmid), Not pal $=N$. palustris (Duftschmid), Syn fov = Syntomus foveayus (Geoffroy), Syn tru $=S$. truncatellus (Linnaeus), Pte str $=$ Pterostichus strenuus (Panzer), Pte ver $=P$. vernalis (Panzer)

The five habitat types supported different densities of hibernating predators. In this study, herbaceous field margins and ditch vegetation supported the highest predator densities (Table 2). These habitats have a dense and tall vegetation cover $(30-50 \mathrm{~cm})$ and may provide suitable microclimatic conditions in winter (Dennis et al. 1994). For instance, Burki and Hausammann (1993) demonstrated that the minimum soil temperatures in dense weed strips were $5^{\circ} \mathrm{C}$ higher than in arable fields. Predator densities in forest edges and grassy field margins were lower than in herbaceous habitats (Table 2). However, as these habitats covered a much larger area than the herbaceous habitats, the total number of predators hibernating in forest edges and grassy field margins may still have been considerable. Linyphiidae were the only predators with a clear preference for grassy habitats. This family is active at temperatures as low as $0.5^{\circ} \mathrm{C}$ and may have an improved winter coldhardiness as compared to most other spiders that hibernate in herbaceous habitats (Bayram and Luff 1993).

In our study, we showed that non-crop habitats, in particular those that contain herbaceous vegetation, are important hibernation sites for generalist

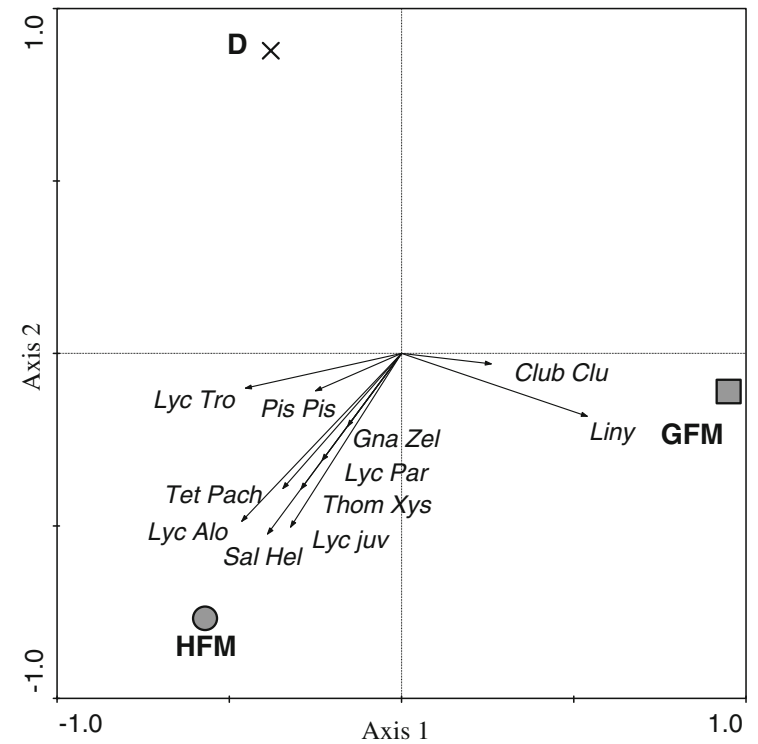

Fig. 4 Biplot diagram of the redundancy analysis focussing on the distribution of spiders in Achterberg in the ditch (D), grassy (GFM) and herbaceous field margins (HFM). Species scores are divided by their standard deviations. The first ordination axis (axis 1) had an eigenvalue of 0.23 and speciesenvironment correlation of 0.63 . The second ordination axis (axis 2) had an eigenvalue of 0.10 and species-environment correlation of 0.67. Club Clu=Clubionidae Clubiona (Latreille), Gna Zel= Gnaphosidae Zelotes (Gistel), Lyc Alo = Lycosidae Alopecosa (Simon), Lyc Par = Lycosidae Pardosa (Koch), Lyc Tro = Lycosidae Trochosa (Koch), Lyc $j u v=$ Lycosidae juvenile, Pis Pis = Pisauridae Pisaura (Simon), Sal Hel = Salticidae Heliophanus (Koch), Thom Xys = Thomisidae Xysticus $($ Koch), Tet Pach = Tetragnathidae Pachygnatha (Sundevall), Liny = Linyphiidae

predators. Unmanaged margins near crop fields may, therefore, act as sources of natural enemies that colonise arable fields in the spring. Therefore, the establishment of non-crop habitats not only increases the aesthetic and recreational value of agricultural landscapes, but it may also boost biological control and reduce the dependency on chemical pesticides.

Acknowledgments We thank I.M.A. Heitkönig (Resource Ecology Group, Wageningen University and Research Centre) and C.J.F. ter Braak (Biometris, Plant Research International) for the statistical advice, and J. Burgers, W.K.R.E. van Wingerden (both Alterra, Wageningen University and Research Centre) and I.M.G. Vollhardt (Department of Agroecology, Georg-August University, Göttingen, Germany) for their help in the identification of the arthropods. We further thank D. Kleijn (Nature Conservation and Plant Ecology Group, Wageningen University and Research Centre) for providing the laboratory facilities. We gratefully acknowledge the comments and helpful suggestions from the anonymous reviewers and the editors. 
Open Access This article is distributed under the terms of the Creative Commons Attribution Noncommercial License which permits any noncommercial use, distribution, and reproduction in any medium, provided the original author(s) and source are credited.

\section{References}

Andersen A (1997) Densities of overwintering carabids and staphylinids (Col., Carabidae and Staphylinidae) in cereal and grass fields and their boundaries. J Appl Entomol 121:77-80

Bayram A, Luff ML (1993) Winter abundance and diversity of lycosids (Lycosidae, Araneae) and other spiders in grass tussocks in a field margin. Pedobiologia 37:357-364

Bianchi FJJA, van der Werf W (2003) The effect of the area and configuration of hibernation sites on the control of aphids by Coccinella septempunctata (Coleoptera: Coccinellidae) in agricultural landscapes: a simulation study. Environ Entomol 32:1290-1304

Bianchi FJJA, Booij CJH, Tscharntke T (2006) Sustainable pest regulation in agricultural landscapes: a review on landscape composition, biodiversity and natural pest control. Proc R Soc Lond B Biol Sci 273:1715-1727

Burki HM, Hausammann A (1993) Überwinterung von Arthropoden im Boden und an Ackerkräutern kunstlich angelegter Ackerkrautstreifen. Bern, Verlag Paul Haupt

Chang GC, Kareiva P (1999) The case for indigenous generalists in biological control. In: Hawkins BA, Cornell HV (eds) Theoretical approaches to biological control. Cambridge University Press, Cambridge, pp 103-115

Chiverton PA (1986) Predator density manipulation and its effects on populations of Rhopalosiphum padi (Hom.: Aphididae) in spring barley. Ann Appl Biol 109:49-60

Coombes DS, Sotherton NW (1986) The dispersal and distribution of polyphagous predatory coleoptera in cereals. Ann Appl Biol 108:461-474

Dennis P, Fry GLA (1992) Field margins: can they enhance natural enemy population densities and general arthropod diversity on farmland? Agric Ecosyst Environ 40:95-115

Dennis P, Thomas MB, Sotherton NW (1994) Structural features of field boundaries which influence the overwintering densities of beneficial arthropod predators. J Appl Ecol $31: 361-370$
Duelli P, Obrist MK (2003) Regional biodiversity in an agricultural landscape: the contribution of seminatural habitat islands. Basic Appl Ecol 4:129-138

Freier B, Gruel HJ (1993) Vorkommen und Bedeutung von Marienkäfern (Coccinellidae) als Nützlinge in AgrarÖkosystemen. Gesunde Pflanzen 45:300-307

Gurr GM, Wratten SD, Luna JM (2003) Multi-function agricultural biodiversity: pest management and other benefits. Basic Appl Ecol 4:107-116

Landis DA, Wratten SD, Gurr GM (2000) Habitat management to conserve natural enemies of arthropod pests in agriculture. Annu Rev Entomol 45:175-201

Lys JA, Nentwig W (1994) Improvement of the overwintering sites for Carabidae, Staphylinidae and Araneae by stripmanagement in a cereal field. Pedobiologia 38:238-242

Manhoudt AGE, de Snoo GR (2003) A quantitative survey of semi-natural habitats on Dutch arable farms. Agric Ecosyst Environ 97:235-240

Pfiffner L, Luka H (2000) Overwintering of arthropods in soils of arable fields and adjacent semi-natural habitats. Agric Ecosyst Environ 78:215-222

Symondson WOC, Sunderland KD, Greenstone MH (2002) Can generalist predators be effective biocontrol agents? Annu Rev Entomol 47:561-594

ter Braak CJF, Šmilauer P (2002) CANOCO reference manual and CanoDraw for Windows user's guide: software for canonical community ordination (version 4.5). Ithaca, NY, Microcomputer Power

Thomas MB, Wratten SD, Sotherton NW (1991) Creation of "island" habitats in farmland to manipulate populations of beneficial arthropods: predator densities and emigration. J Appl Ecol 28:906-917

Tscharntke T, Bommarco R, Clough Y, Crist TO, Kleijn D, Rand TA, Tylianakis JM, van Nouhuys S, Vidal S (2007) Conservation biological control and enemy diversity on a landscape scale. Biol Control 43:294-309

Turin H, Blankevoort B, Bosch EJ, van Noortwijk I (2000) Carabidae of the Netherlands: their distribution and ecology. Nationaal Natuurhistorisch Museum Naturalis, Leiden (in Dutch)

Westmacott R, Worthington T (1997) Agricultural landscapes: a third look. Cheltenham, Countryside Commission

Wilkinson RT, Landis DA (2005) Habitat diversification in biological control: the role of plant resources. In: Wäckers FL, van Rijn PCJ, Bruin J (eds) Plant-provided food for carnivorous insects: a protective mutualism and its applications. Cambridge University Press, New York, pp 1-14 